\title{
DEVELOPMENT OF PERFORMANCE EVALUATION INDICATORS FOR SOCIAL ENTERPRISES: THE USE OF DELPHI TECHNIQUE
}

\author{
Petra TAUŠL PROCHÁZKOVÁ ¿D, Marta NOSKOVÁ (D), \\ Kristýna MACHOVÁ (D, Veronika VELÍŠKOVÁ (DD \\ Department of Business Administration and Management, Faculty of Economics, \\ University of West Bohemia, Pilsen, Czech Republic
}

Received 16 November 2020; accepted 27 April 2021

\begin{abstract}
Social enterprises have become a natural part of the economy. Their importance is significantly increasing, as well as the need to evaluate their performance. There are different points of view on the indicators and methods used to evaluate their performance and they often lack simplicity and are costly and time consuming. Thus, this study aims to identify and discuss performance evaluation indicators for social enterprises with particular focus on identifying a set of indicators that might be applied without placing high demands on each social enterprise. A two-phase approach was adopted and applied in the Czech social entrepreneurship environment. First, the Delphi technique was used to get a set of indicators for each of the areas of the triple bottom line principles. Consequently, an empirical examination of these indicators using a set of social enterprises was conducted. Final results were determined using Technique for Order of Preference by Similarity to Ideal Solution (TOPSIS). As a result, a set of twelve indicators that cover social, economic, environmental and local areas are proposed. These indicators reflect the opinions of experts in the field as well as their practical usefulness, which is discussed at the end of the paper.
\end{abstract}

Keywords: social enterprise, performance indicators, Delphi method, development of indicators, triple bottom line, indicator proposal.

JEL Classification: L25, L26, L21.

\section{Introduction}

It has been widely discussed among scholars that social entrepreneurship possesses a permanent and important position in an economy (Alarifi et al., 2019; Bacq \& Janssen, 2011). There is a growing body of literature aimed at investigating various fields of social entrepreneurship with great attention placed on the public sector. However, there is a lack of a unifying paradigm in the field of social entrepreneurship (Bacq \& Janssen, 2011) and from many

\footnotetext{
${ }^{\star}$ Corresponding author. E-mail: mnosk@kpm.zcu.cz
} 
perspectives, despite the great attention, the level of knowledge on social entrepreneurship may be considered as still in its infancy (Bacq \& Janssen, 2011; Saebi et al., 2019).

Research in social entrepreneurship remains fragmented and disorganized. There are several streams of interest. One of them concentrates on the evaluation, measurement, and the performance indicators of social enterprises. This scope has been attracting significant attention and presents very comprehensive and challenging questions (Bagnoli \& Megali, 2011; Crucke \& Decramer, 2016; Ebrahim \& Rangan, 2014; Irene et al., 2016; Kraus et al., 2017).

In order to understand the importance of evaluation and setting performance indicators, it is essential to understand how social enterprises are understood and what kind of specifics are related to them. In a nutshell, social enterprises is a segment that follows social and/ or environmental missions while simultaneously fulfilling basic economic principles (AbuSaifan, 2012; Canestrino et al., 2020). The application of triple bottom line principle is well established (Elkington, 1998).

However, across regions, there is a difference in understanding what kind of subjects may be considered as social enterprise. Bacq and Janssen (2011) discuss different schools of thought: American Social Innovation School, American Social Enterprise School, and European School. These schools follow different approaches to social entrepreneurship and social enterprises. For the aim of this study, the European approach is considered as the most significant. In Europe, attention is turned to the concept of social enterprise. A social enterprise is hence understood as per the conceptual and legal definition (Alegre et al., 2017; Bacq \& Janssen, 2011; European Commission, 2020). While conceptual definition follows characteristic attributes such as pursuing explicit social/environmental missions for the community, profit distribution limits, involvement of stakeholders, independent governance related to ownership structure; the legal definition is related to setting legal and institutional norms that are specially created in order to support social entrepreneurial subjects. To sum up the current legal status quo in Europe, social enterprises adhere to such legislation/statutes designed especially for social enterprises and/or via existing legal forms that establish social enterprise criteria.

For studying the aspects of social enterprises, performance evaluation is important because social enterprises operate on the same market as other commercial enterprises that face similar situations. However, in comparison to these organizations, whose performances can be expressed relatively easily by using tangible and quantifiable indicators, it is much more complex to identify performance indicators for social enterprises. They might also be accountable to a greater number of stakeholders and expectations. Hence, the evaluation of a social enterprise's performance remains a complicated issue in regard to stakeholder relations. Further, the majority of social enterprises are supported by governmental or other initiatives. Hence, despite the effort to reach financial independence, many social enterprises depend on multi-source financing. Thus, Crucke and Decramer (2016) argue, the proper evaluation of social enterprise performances may send a clear signal that social enterprises are managed well, the financial resources are used effectively, and the aim of the social enterprise is met. In this context, the attempts to construct performance evaluation indicators that might be applied on a large scale to social enterprises are considered as critical to the future development of social enterprises. 
This article aims to open up aspects of performance evaluation indicators of social enterprises by proposing a set of indicators using the Delphi technique and keeping in mind the requirement to optimally get and measure these indicators without requiring massive time and financial demands and also active cooperation from social enterprises themselves. To evaluate the indicators in practice a comparative analysis on a sample of social enterprises follows the Delphi technique.

The next part of the study is as follows. Theoretical background in the context of various evaluation approaches of social enterprises' performance is given in the first section. Next, the section describes data, methods, and the empirical approach. The following section, Results, presents results of the Delphi technique that are empirically applied and compared to a sample of social enterprises. The last section of the study discusses findings and potential implications on practice. It also provides suggestions for future research.

\section{Theoretical background}

Despite all the concepts and suggestions that have been discussed regarding performance evaluation, research in this field still falls behind in practice (Rawhouser et al., 2019). Thus, the next part of the study concentrates on discussing the various approaches to the evaluation and the performance indicators of social enterprises.

In addition, following section focuses on the review of empirical applications of evaluation tools in the Czech Republic in order to see how much has already been done in practice.

The research in this rubric is processed in several ways. The first stream uses and modifies existing indicators and methods designed for the business sector (Emerson, 2003; Gray, 2001; Somers, 2005). A second stream is formed by scholars who formulate new models and indicators (Crucke \& Decramer, 2016; McLoughlin et al., 2009; New Economics Foundation, 2007) and finally the third stream is trying to categorize and review current approaches in order to get feedback on them (Arena et al., 2015; Bagnoli \& Megali, 2011; Chmelik et al., 2015).

OECD (2015) mentions two main approaches to performance measurement. The first approach works with a set of indicators pre-defined for each triple bottom line perspective with limited consideration of the size or the sector of activity of the social enterprise. The second approach pays greater attention to individual metrics tailored to individual social enterprises.

To sum up, the field of discussion is very open and broad. Individual indicators and methods are discussed in detail and a comprehensive approach with the ambition to classify these indicators to particular rubrics is on the agenda too. Table 1 outlines a list of various categories that have been identified by several scholars with the ambition to classify approaches to social enterprises' performance measurement. Even though the list is not totally comprehensive, it clearly demonstrates how wide the spectrum of this rubric is and how different (or similar) scholars understand the approaches, and upon a closer look at how demanding many of these approaches are. 
Table 1. Various identified categories of social enterprises measurement (source: Arena et al., 2015; Ebrahim \& Rangan, 2014; Reeder \& Colantonio, 2013; Maas \& Liket, 2011; New Economic Foundation, 2007)

\begin{tabular}{|c|c|}
\hline Author(s) & Approaches \\
\hline $\begin{array}{l}\text { Reeder and Colantonio } \\
\text { (2013) }\end{array}$ & $\begin{array}{l}\text { Bottom-up perspectives: (a) Social audit, (b) SROI } \\
\text { Statistical approaches to assessing changes: (a) Before and after } \\
\text { comparison, (b) Randomized control trial, (c) Cost Effectiveness } \\
\text { Analysis, (d) Cost Benefit Analysis. } \\
\text { Collation of indicators of relevant results: (a) Balanced scorecard, } \\
\text { (b) Multicriteria dimension analysis, (c) Rating system. } \\
\text { Expert opinions: (a) Delphi method, (b) Standards - yes/no response } \\
\text { whether a particular standard has been met. }\end{array}$ \\
\hline $\begin{array}{l}\text { Ebrahim and Rangan } \\
(2014)\end{array}$ & $\begin{array}{l}\text { Logic models based on the input-output-outcome-impact chain. } \\
\text { Models using expected returns and cost effectiveness - e.g., (a) SROI, } \\
\text { (b) The best available charitable option, (c) Benefit-Cost Ratio. } \\
\text { Experimental methods - e.g., Randomized control trials. } \\
\text { Integrative models - e.g., (a) Balanced scorecard, (b) Strategy maps, } \\
\text { (c) Dashboards. } \\
\text { Participatory and relationship-based methods - e.g., (a) Constituency } \\
\text { feedback and perception reports, (b) Participatory rural appraisal and } \\
\text { variants. }\end{array}$ \\
\hline Arena et al. (2015) & $\begin{array}{l}\text { Process-based models - e.g., (a) MIAA - Methodology for Impact } \\
\text { Analysis and Assessment, (b) SIA - Social Impact Assessment. } \\
\text { Dashboards and scorecards measuring different performance dimensions } \\
\text { - e.g., (a) Balanced scorecard, (b) Public Value Score Card, (c) SIMPLE } \\
\text { - Social Impact for Local Economy, (d) SAVE - Social Added Value } \\
\text { Evaluation. } \\
\text { Synthetic indicators - e.g., (a) SROI, (b) LM3 - Local Multiplier 3, } \\
\text { (c) Gamma Model. }\end{array}$ \\
\hline $\begin{array}{l}\text { New Economic } \\
\text { Foundation (2007) }\end{array}$ & $\begin{array}{l}\text { Holistic methods - e.g., (a) SROI, (b) Social accounting and auditing, } \\
\text { (c) Social reporting standard. } \\
\text { Performance indicators and impact on local economic activities - e.g., } \\
\text { (a) LM3, (b) Input-Output Analysis, (c) Eco-mapping. } \\
\text { Quality improvement indicators of organization performance - e.g., } \\
\text { (a) EFQM Excellence Model, (b) ISO 26000, (c) ISO 9000, (d) SA } 8000 . \\
\text { Methods oriented on strategic management - e.g., (a) Balanced } \\
\text { scorecard, (b) SWOT. }\end{array}$ \\
\hline Maas and Liket (2011) & $\begin{array}{l}\text { Process methods - e.g., (a) Balanced scorecard, (b) SROI, (c) SCA - } \\
\text { Social Compatibility Analysis, (d) Acumen Scorecard, (e) Measuring } \\
\text { impacts toolkit, (f) SEAT - Socioeconomic Assessment Toolbox. } \\
\text { Impact methods - e.g., (a) MIF - Measuring Impact Framework, } \\
\text { (b) OASIS - Ongoing Assessment of Social Impacts, (c) Robin Hood } \\
\text { Foundation Benefit-Cost Ratio, (d) SIA - Social Impact Assessment. } \\
\text { Monetarization methods - e.g., (a) Local multiplier, (b) SCEA - Social } \\
\text { Cost-Effectiveness Analysis, (c) SVA - Stakeholder Value Added, (d) } \\
\text { SROI, (e) SRA - Social Return Assessment, (f) BACO - Best Available } \\
\text { Charitable Option. }\end{array}$ \\
\hline
\end{tabular}




\subsection{Using performance indicators and methods in practice - current state}

Empirical application of concrete evaluation tools is driven by various circumstances, needs, and motivations, e.g., sector of activity, size of social enterprise, or stakeholder's expectations. Thus, the aim of this section is to confront the theoretical background with practice in the social enterprise area in Czech environment. First, it has to be mentioned that social enterprises in the Czech Republic have not been legally defined yet and there are officially no accepted criteria determining social enterprises' identification. However, a common (but not legally) accepted criteria of social enterprises are criteria listed on the website Czech Social Entrepreneurship (2020). There is also no official database of social enterprises, but again the most cited (and commonly accepted) list of Czech social enterprises can be found on the website Czech Social Entrepreneurship (2020). Even though the commonly accepted list covers approx. 230 entities, there is a rough estimation that the number of social enterprises might be significantly higher, around 3,800 subjects (Fraňková, 2019).

There is a limited number of studies that have been applied to performance indicators. A majority of them are individual case studies and papers, some also show surveys conducted among social enterprises, while some are related to the requirement of financial support (mainly EU funds support) provided by institutional bodies.

Concretely, Prochazkova and Noskova (2020) discuss the LM3 method (Local Multiplier 3 method) versus input-output analysis and apply it on a sample of 143 social enterprises; Asmalovskij et al. (2019) analyze indicators related to the financial performance of 112 social enterprises; Pelucha et al. (2017) apply a particular qualitative method using questionnaire investigating three levels of stakeholders (policy-makers, advisers, and social entrepreneurs). Further, Vyskočil (2014) proposes several indicators for evaluation, mainly financial, but also draws attention to social and environmental indicators but in a very limited scope and without empirical application. Bednarikova and Francova (2011) turn attention to SROI and LM3. SROI was calculated by choosing one social enterprise and LM3 was calculated too. In the case of both methods, it turned out that it is not possible to suggest using them on a large-scale under the current conditions of social entrepreneurship in the Czech Republic. There is very limited experience of their applicability and it demands time, financial resources and cooperation from stakeholders. Moreover, LM3 focuses only on the economic aspect.

Another source of performance measurement is several surveys among social enterprises. These surveys are usually organized by individual scholars, institutional bodies, or non-governmental organizations (summary at Fraňková, 2019). A list of the most important ones is analyzed in Prochazkova and Machova (2020). The research reveals that only one research provided by Prochazkova (more in Prochazkova \& Machova, 2020) concentrates on the topic of measurement and gets direct feedback from social enterprises. The findings give quite a clear hint about the situation. There is negligible experience with measurement from the side of social enterprises, and if there is any, it is in the form of individual indicators related to financial and social/environmental missions. SROI was actively computed by a few enterprises and occasionally another method was mentioned - e.g., Social Earnings Ratio, or cost-benefit analysis. Lastly, Fraňková (2019) mentions support measures specifically addressed to social enterprises, mainly supporting schemes on the level of EU funds. Within these programs, 
performance indicators are usually focused on the physical output (product/services) - e.g., total number of participants/offered services, number of innovative services, number of retrainings, total number of newly established social enterprises etc.

The number of studies and attempts dedicated to social enterprises' performance evaluation is limited and fragmented and there is definitely need for further examination. The reasons for that are several but the main limitations are (a) poor legislative background, (b) limited data availability in social enterprises' mapping efforts, and (c) limited spectrum of generally accepted indicators/evaluation frameworks.

\section{Materials and methods}

It is clear that there are many different approaches to the measurement of a social enterprise's performance. One possibility is the use of the Delphi method, that has been widely used for the purpose of indicator development. For example, Musa et al. (2015) used it to develop environmental well-being indicators for the evaluation of urban sustainability in Malaysia. In the same country, Ahmad and Wong (2019) developed weighted triple-bottom line sustainability indicators for the food manufacturing industry. Sustainability development was also the main aim of Chang and Cheng (2019) who identified "key sustainability indicators that play a vital role in boosting the sustainable performance of manufacturing SMEs" (Chang \& Cheng, 2019, p. 458). And at last, in Europe, Meijering et al. (2018) used the Delphi method to identify the most relevant components of urban sustainability.

Very little was found on the use of Delphi method for the purpose of indicator development that would measure the performance of social enterprises. The exception is the work of Crucke and Decramer (2016), who proposed measurement instruments for organizational performance of social enterprises and in one phase of the research used the Delphi method. Also, Kraus et al. (2017) partly used Delphi method in order to measure social entrepreneurship orientation (thus, the aim of their paper was not to assess the performance of the enterprise). Also, Kavoura and Andersson (2016) applied the Delphi method in order to develop a strategy for an entrepreneurship counseling design, and according to the authors, their results may well apply to non-profit organizations (thus again, the aim of their paper was not to develop indicators).

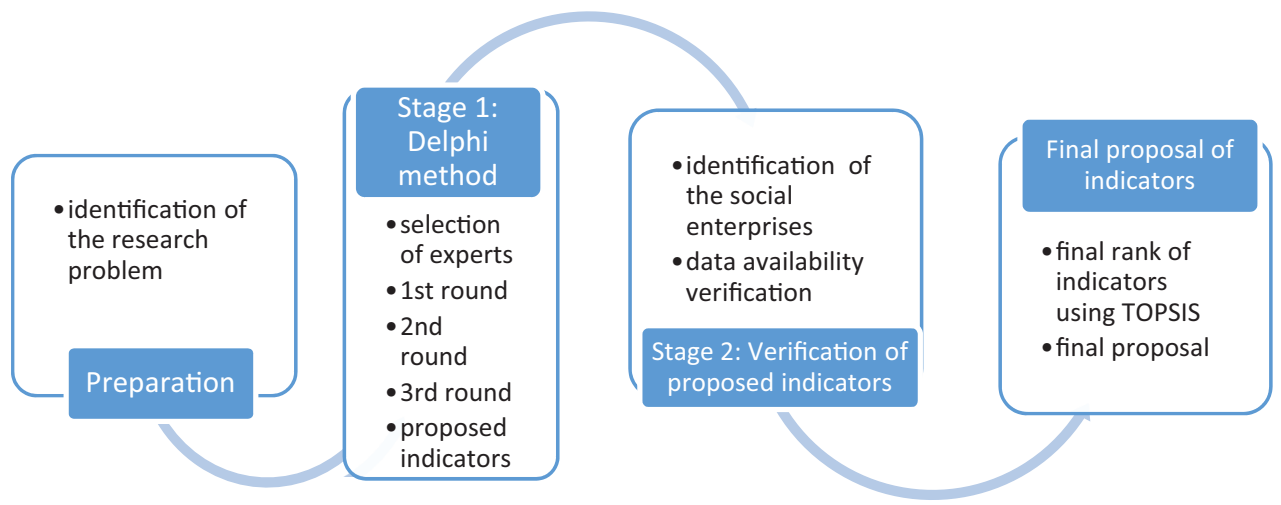

Figure 1. Design of the research 
Given the positive experiences of these authors with the Delphi method, it was decided to base this research on the same method. This study has a two-stage design (see Figure 1). In stage 1, the Delphi method was used and as a result, a set of proposed indicators was developed. Indicators are divided into 3 sections based on triple bottom line concept as the essential underpinnings of social entrepreneurship philosophy (see section Introduction, e.g. Abu-Saifan, 2012; Elkington, 1998; OECD, 2015). In stage 2, these indicators were tested in order to verify their usefulness empirically. Thus, in the next part, both stages will be described in terms of methodology as well as the method used for compilation of final proposal of indicators.

\subsection{Delphi method}

The Delphi procedure is based on a multi-round controlled survey among a group of experts in order to obtain the most reliable consensus of opinion (Dalkey \& Helmer, 1962). The procedure makes it possible to work with a group of individuals as a whole, and thus, efficiently handle a given problem. Experts in the field are asked to participate in the survey that is focused on a specific problem (Okoli \& Pawlowski, 2004).

This type of research can be used, for example, to forecast the future, to help identify problems and their solutions, set goals and priorities, or to delineate differences among several reference groups (Delbecq et al., 1975). Modern usage was analyzed by Flostrand et al. (2020), who provided extensive bibliographic analysis of the methods' use since 1975.

The method assumes that the expert in the field is better oriented to the issue than a person who does not have a great knowledge of the topic. Therefore, the selection of participating experts is crucial for the successful conduct of the Delphi method. Opinions on the optimum number of experts also differ, Landeta (2006) report the ideal range between 7 and 30, Gordon (1994) suggests 15-35 people and Witkin and Altschuld (1995) suggests below 50 people. When addressing experts, it is important to count on a limited rate of return, which should be between 35-75\% (Gordon, 1994). Ensuring anonymity and consensus among participants is an important element of this approach.

The Delphi method is processed in several rounds, usually three, with two rounds being considered as a minimum (Linstone \& Turoff, 1975). Ludwig (1997) and Crucke and Decramer (2016) warn that 3 rounds are sufficient to find the desired answers and no longer distort data.

The actual processing of the Delphi results may vary. The most common tool for obtaining a characteristic of group judgment is processing the results through basic descriptive statistics (median, modus, mean or standard deviation). Also, the Wilcoxon test or the Kendall coefficient of conformity is commonly used (Egerová \& Mužík, 2010; García-Uceda et al., 2017). For the processing of the Delphi method presented in this study the procedure described and used by Egerová and Mužík (2010), García-Uceda et al. (2017) was applied.

\subsubsection{Delphi research - description}

The investigation itself took place in January and February 2018. At this stage, a research problem was identified, a suitable group of experts was selected, and a small group of 
Table 2. Groups of experts (source: own, 2020)

\section{Group 1 - State sphere}

- representatives from the state sphere dealing with the field of social entrepreneurship

- e.g. The Ministry of Labour and Social Affairs

\section{Group 2 - Academic}

- academic researchers interested in social entrepreneurship

\section{Group 3: Nonprofit Representatives}

- associations

- professional associations

- clusters dealing with social entrepreneurship

\section{Group 4: Private sector}

- professional consultants specializing in social counseling

- experts in the field of program project support intended for social entrepreneurship

experts was used for pilot research. The task of the experts was to propose indicators for each triple bottom line area - social, economic, and environmental/local (more in the section Results).

The basic criterion of the expert selection was the fact that the respondent must know the area of social entrepreneurship, have knowledge of this area, be oriented in it, and have either work or expertise in it. Managers and owners of social enterprises were excluded from the selection.

Finally, several expert groups were identified. Representatives from the areas shown in Table 2 were involved.

In total, 70 experts were identified. The first round was attended by 30 experts $(43 \%$ return), the second round was attended by 22 of the 30 experts, and the third round was attended by 19 people. Overall, the sample was very satisfactory and sufficient.

In the first round, experts were asked to identify 2-5 indicators for each area of triple bottom line principle that they consider as appropriate for social enterprises to report in order to measure their performance.

The second round was based on the answers from the first round. The experts involved were asked to determine the importance of proposed indicators. The expert assigned 1 to 5 points to each indicator, where the value of 5 corresponded to the highest degree of importance.

Indicators for the third round were sorted according to the results from the second round and only eight indicators for each area were used. If more factors are used, there is a risk of confusion or unwillingness to cooperate by experts in the next round. 
The task of the experts was to consider the order from the second round and adjust it to its final form (scale from 1 to 8 , where 8 has the highest importance). For each factor, the ranking was summed and the Kendall's coefficient of concordance was calculated.

The Kendall's coefficient of concordance allows us to determine the tightness of the relationship between individual rankings. The coefficient ranges from 0 (no agreement) to 1 (complete agreement).

The following formula was used to calculate this coefficient:

$$
W=\frac{\sum X^{2}-\frac{\left(\sum X\right)^{2}}{n}}{\frac{1}{12} k^{2}\left(n^{3}-n\right)},
$$

where $W$ - value of Kendall's coefficient; $X$ - sum of points given to individual factor; $n$ number of examined factors; $k$ - number of experts (Chráska, 2017).

\subsection{Verification of proposed indicators}

After obtaining the set of indicators from the Delphi method, it was decided to verify their practical use. This decision was based on finding, that even if there are some researches that propose indicators for Social Enteprises (as was state in section 1.1.), they are not usually empirically tested (e.g. Vyskočil, 2014, Bednarikova \& Francova, 2011). The aim of this study is to propose indicators in line with social enterprises' philosophy (applied on triple bottom line), that are easy to find, and publicly available. Thus, it is necessary to test the proposed indicators in order to find how often they are reported on the websites of social enterprises, or in public databases. For this purpose, the list of social enterprises was compiled and a total of 319 social enterprises were identified. These subjects were identified using several sources. The main source was the website Czech Social Entrepreneurship (2020), further sources (Association of Social Responsibility, the Cluster of Social Innovation and Enterprises, the Chamber of Social Enterprises) including a self-identified group of social enterprises by authors' business register search were used as well. The final database of 319 social enterprises represents the largest such database in the Czech Republic with more than $81 \%$ as work integrated social enterprises and the rest as social enterprises. Such a ratio indicates the structure of social enterprises in the Czech environment.

After identifying the sample of social enterprises, websites and public databases were searched in order to find which of the proposed indicators (or the information that is necessary to compile the indicators), are possible to find for each social enterprise from the list. Also, the quality of information was evaluated.

\subsection{Final proposal of indicators}

In order to process the results of the two stages together, it was decided to use one of the Multiple Criteria Decision Making Techniques (MCDM), namely TOPSIS developed by Hwang and Yoon (1981). The main principle of this method is that "chosen solution should be as 
Table 3. Indicators proposed after the first round (source: own, 2020)

\section{Social}

- Number of jobs created and total number of employees including determination of the number of jobs created for disadvantaged group of persons

- Number of disadvantaged group of clients who have been assisted by the Social Enterprise (for example, Social Enterprise focused on education - provision of educational services) and identification of the

disadvantaged group

- Staff development (number)

- Number of social services provided

- Employee turnover

- Characteristics of creating conditions for work-life balance of employees

- Description of increasing the level of working conditions in the workplace

- Increasing the qualification of employees

- Form of social inclusion

- Providing psychosocial support to disadvantaged groups

- Methods of employee motivation

- Declaration and publication of socially beneficial activities (short description)

- Gender policy

- Employee participation in company management

- Age structure of employees

- Corporate Culture

- Fair pay system (no discrimination on the grounds of age, gender etc.)

- Diversity management

- Innovative solution of social problems

- Measuring customer satisfaction

\section{Economic}

- Revenues from the sale of own products, services and sold goods

- Revenues share per employee of social enterprise

- Share of revenues from the sale of own products, services and sold goods of the total revenues (value should be at least $50 \%$ )

- Publication of complete financial statements (profit and loss account, balance sheet, notes)

- Social audit

- Cash flow

- Proportion of money reinvested on the social enterprises'development

- Profit/loss

- Return on assets

- Return of equity

- Wage costs

- Additional costs associated with employing a disadvantaged group of persons

- Share of financing sources

- Description of risk diversification (eg multiple business areas / multiple clients / multiple partners / multiple projects at once)

- Market share compared to the biggest competition

- Balanced Scorecard

- Value for Money methodology

- Mission, vision or strategy existence

- SROI

\section{Environmental/local}

- Transparent supply chain

- Number of local suppliers and total number of suppliers

- Environmentally friendly production cycle and its reporting

- Number of products and services with environmental impact

- Identification of key inputs and determination if they are local inputs

- Energy consumption

- Waste treatment (recycling) and use of renewable resources

- Waste disposal

- Satisfying local demand / needs

- Saving $\mathrm{CO}_{2}$ and emissions (eg by reducing transport distances, etc.)

- Environmental impacts of the company and its products / business in accordance with the principles of environmental protection

- Employing local human resources

- Evaluating the impact of activities on the local community (local aspect of functioning)

- Cooperation with the local community

- Share of local customers

- Reporting socially responsible principles and standards that an enterprise adheres to (e.g. Uited Nation Global Compact)

- Promotion of biodiversity and agrobiodiversity

- Consideration of environmental aspects in decision-making (for example in supplier-customer relationship) 
close to the positive ideal solution as possible and as far away from the negative ideal solution as possible" (Hwang et al., 1993, p. 889). In this paper, points given by experts in the last round of Delphi (thus Delphi results) were used as criterion A, and points that each indicator received in the process of empirical verification (if researched enterprise published the sought information, the indicator obtained one point), were used as criterion B. The advantage of TOPSIS method is, that it normalizes data for both criteria, thus it does not matter that the scoring system was different at the beginning. Also, it was decided to prioritize criterion A (regarding Delphi results) and give its points $2 / 3$ weight, while points in criterion B has $1 / 3$ weight. The reason is that from the Delphi method, resulting indicators represent opinions of the experts in the field and it is a set of high-quality and well-thought-out indicators. Its results cannot be omitted easily because of the inability of enterprises to publish the recommended information. After the compilation of the final rankings, 4 indicators with the highest values were selected for each area as the recommended indicators that should be used to evaluate the performance of social enterprises.

\section{Results}

\subsection{The first Delphi round - results}

After obtaining the responses, synthesis was used to unify similarly formulated answers. In the first section of the survey, the largest number of proposed indicators were identified for the social principle (20), for the economic principle (19) and subsequently for environmental (local) benefits (18). The results are shown in Table 3.

\subsection{The second Delphi round - results}

The experts' answers were collected and analyzed. The weighted average of points assigned for individual indicators was calculated. Ranks of indicators for this round can be seen as the first column in Tables 4, 5 and 6.

\subsection{The third Delphi round - final results}

The results of the third round (thus the whole results of the stage 1 of this research) are showed in the Table 4, 5 and 6. As for the results of Social Area (see Table 4) the Kendall coefficient was $\mathrm{W}=0.202$, which indicates a considerable discrepancy between the opinions of the surveyed experts, but with regard to the results of the other indicators, this is the largest agreement in the survey.

Looking at Table 5 representing the economic indicators, these are simple indicators that should not be difficult for a social enterprise to report (there are several indicators, that can be directly found in the financial statement). On the other hand, many social enterprises, as confirmed by Prochazkova and Machova (2020), do not publish their financial statements even if it is a public obligation. The Kendall coefficient for the Economic Area was $\mathrm{W}=0.0696$, which indicates a large discrepancy between the opinions of the experts surveyed. 
Table 4. Indicators for social area - third round results (source: own, 2020)

\begin{tabular}{|c|l|c|c|}
\hline $\begin{array}{c}\text { Second } \\
\text { Round } \\
\text { rank }\end{array}$ & \multicolumn{1}{|c|}{ Social indicators (S) } & Rank & $\begin{array}{c}\text { Sum of } \\
\text { assigned } \\
\text { ranks (X) }\end{array}$ \\
\hline 2. & $\begin{array}{l}\text { S1: Number of disadvantaged group of clients who have been } \\
\text { assisted by the SE (for example, SE focused on education - } \\
\text { provision of educational services) and identification of the } \\
\text { disadvantaged group }\end{array}$ & 1. & 125 \\
\hline 1. & $\begin{array}{l}\text { S2: Number of jobs created and total number of employees } \\
\text { including determination of the number of jobs created for } \\
\text { disadvantaged group of persons }\end{array}$ & 2. & 108 \\
\hline 5. & S3: Increasing the qualification of employees & 3. & 84 \\
\hline 3. & S4: Form of social inclusion & 4. & 80 \\
\hline 4. & S5: Providing psychosocial support to disadvantaged groups & $5 .-6$. & 79 \\
\hline 7. & S6: A fair pay system & $5 .-6$. & 79 \\
\hline 6. & $\begin{array}{l}\text { S7: Declaration and publication of socially beneficial activities } \\
\text { (short description) }\end{array}$ & 7. & 65 \\
\hline 8. & S8: Methods of employee motivation & 8. & 64 \\
\hline
\end{tabular}

Table 5. Indicators for economic area - third round results (source: own, 2020)

\begin{tabular}{|c|l|c|c|}
\hline $\begin{array}{c}\text { Second } \\
\text { Round } \\
\text { rank }\end{array}$ & \multicolumn{1}{|c|}{ Economic indicators (EC) } & Rank & $\begin{array}{c}\text { Sum of } \\
\text { assigned } \\
\text { ranks (X) }\end{array}$ \\
\hline 2. & $\begin{array}{l}\text { EC1: Revenues from the sale of own products, services, and sold } \\
\text { goods }\end{array}$ & 1. & 102 \\
\hline 4. & $\begin{array}{l}\text { EC2: Proportion of money reinvested on the social enterprises' } \\
\text { development }\end{array}$ & 2. & 93 \\
\hline 1. & EC3: Profit/loss & 3. & 91 \\
\hline 3. & $\begin{array}{l}\text { EC4: Publication of complete financial statements (profit and } \\
\text { loss account, balance sheet, notes) }\end{array}$ & $4 .-5$. & 88 \\
\hline 5. & EC5: Mission, vision or strategy existence & $4 .-5$. & 88 \\
\hline 7. & $\begin{array}{l}\text { EC6: Share of revenues from the sale of own products, services } \\
\text { and sold goods of the total revenues (value should be at least } \\
50 \%)\end{array}$ & 6. & 86 \\
\hline 8. & $\begin{array}{l}\text { EC7: Additional costs associated with employing a } \\
\text { disadvantaged group of persons }\end{array}$ & 7. & 62 \\
\hline 6. & EC8: Share of financing sources & 8. & 74 \\
\hline
\end{tabular}

Looking at Table 6 it can be stated that in the environmental (local) area, the emphasis is placed on local aspects and problems, and less on environmental elements. The local perspective is entirely in line with the philosophy of social entrepreneurship. The Kendall coefficient of agreement has the value $\mathrm{W}=0.193$, which shows a great disparity between the opinions of the experts surveyed. 
Table 6. Indicators for environmental (local) area - third round results (source: own, 2020)

\begin{tabular}{|c|l|c|c|}
\hline $\begin{array}{c}\text { Second } \\
\text { Round } \\
\text { rank }\end{array}$ & \multicolumn{1}{|c|}{ Environmental/local indicators (EN) } & Rank & $\begin{array}{c}\text { Sum of } \\
\text { assigned } \\
\text { ranks (X) }\end{array}$ \\
\hline 2. & EN1: Employing local human resources & 1. & 111 \\
\hline 1. & EN2: Cooperation with the local community & 2. & 107 \\
\hline 8. & EN3: Satisfying local demand / needs & 3. & 97 \\
\hline 3. & $\begin{array}{l}\text { EN4: Evaluating the impact of activities on the local community } \\
\text { (local aspect of functioning) }\end{array}$ & 4. & 92 \\
\hline 4. & $\begin{array}{l}\text { EN5: Environmentally friendly production cycle and its } \\
\text { reporting }\end{array}$ & 5. & 81 \\
\hline 6. & EN6: Number of local suppliers and total number of suppliers & 6. & 75 \\
\hline 7. & EN7: Waste treatment (recycling) and use of renewable resources & 7. & 72 \\
\hline 5. & EN8: Transparent supply chain & 8. & 49 \\
\hline
\end{tabular}

\subsection{Conclusions of Delphi method}

As can be seen, the experts have proposed simple indicators that are real and achievable for reporting purposes. Experts proposed quantitative as well as qualitative indicators and prefer the way of a unified set of indicators over a specific tailored set of indicators that might not be applicable to every social enterprise.

A fact that cannot be neglected is the relatively low agreement between individual experts (measured by Kendall's coefficient of concordance). It was observed in each of the areas but the lowest agreement was observed in economic indicators. This can be attributed to the diversity of this working group. It can be assumed that academics may have a different opinion than, for example, professional advisors.

\subsection{Verification of proposed indicators and final rank of indicators}

At the second stage of this research, websites and available databases (e.g., Albertina Gold edition; Business Register) were searched in order to find out, which of the proposed indicators (or related information), are possible to find for the selected social enterprises.

The results of this research (stage 2) can be seen in the left parts of the following three tables. In Table 7, there are final results for the social area. It is visible, that the original ranking from the Delphi method was influenced by the ranking from the empirical results. As far as the first four indicators, indicators S4, S7, S1, and S2 are recommended as the most important ones for the performance evaluation.

Considering the economic area, Table 8 shows that the biggest change (comparing to the Delphi ranking) occurred in the indicator EC2. This information is published so rarely, that it puts this indicator on the sixth place in the final ranking. Thus, the recommended ones from this analysis are EC1, EC3, EC4, and EC5. 
Table 7. Final rank of indicators in social area (source: own, 2020)

\begin{tabular}{|c|c|c|c|c|c|c|}
\hline & \multicolumn{2}{|c|}{ Criterion A (weight 0.33) } & \multicolumn{2}{c|}{ Criterion B (weight 0.67) } & \multicolumn{2}{|c|}{} \\
\cline { 2 - 7 } & $\begin{array}{c}\text { Empirical } \\
\text { results }\end{array}$ & Rank & $\begin{array}{c}\text { Delphi points } \\
\text { results }\end{array}$ & Rank & $\begin{array}{c}\text { TOPSIS } \\
\text { Score }\end{array}$ & Final Rank \\
\hline S1 & 30 & 6 & 125 & 1 & 0.494 & 3. \\
\hline S2 & 53 & 4 & 108 & 2 & 0.486 & 4. \\
\hline S3 & 60 & 3 & 84 & 3 & 0.368 & 5. \\
\hline S4 & 149 & 1 & 80 & 4 & 0.641 & 1. \\
\hline S5 & 52 & 5 & 79 & 5.5 & 0.304 & 6. \\
\hline S6 & 6 & 7 & 79 & 5.5 & 0.144 & 7. \\
\hline S7 & 143 & 2 & 65 & 7 & 0.557 & 2. \\
\hline S8 & 3 & 8 & 64 & 8 & 0 & 8. \\
\hline
\end{tabular}

Table 8. Final rank of indicators in economic area (source: own, 2020)

\begin{tabular}{|c|c|c|c|c|c|c|}
\hline & \multicolumn{2}{|c|}{ Criterion A (weight 0.33) } & \multicolumn{2}{c|}{ Criterion B (weight 0.67) } & \multicolumn{2}{|c|}{} \\
\cline { 2 - 7 } & $\begin{array}{c}\text { Empirical } \\
\text { results }\end{array}$ & Rank & $\begin{array}{c}\text { Delphi points } \\
\text { results }\end{array}$ & Rank & $\begin{array}{c}\text { TOPSIS } \\
\text { Score }\end{array}$ & Final Rank \\
\hline EC1 & 185 & 2 & 102 & 1 & 0.957 & 1 \\
\hline EC2 & 56 & 6 & 93 & 2 & 0.443 & 6 \\
\hline EC3 & 195 & 1 & 91 & 3 & 0.861 & 2 \\
\hline EC4 & 175 & 3 & 88 & 4.5 & 0.799 & 3 \\
\hline EC5 & 165 & 4 & 88 & 4.5 & 0.775 & 4 \\
\hline EC6 & 109 & 5 & 86 & 6 & 0.571 & 5 \\
\hline EC7 & 0 & 8 & 74 & 7 & 0.150 & 8 \\
\hline EC8 & 54 & 7 & 62 & 8 & 0.222 & 7 \\
\hline
\end{tabular}

As for the environmental (local) area, Table 9 shows the results. In this area, there are no big differences between the Delphi ranking and the final ranking visible, only one minor switch in the ranking of the first two indicators. Thus, the recommended indicators for this area are EN2, EN1, EN3, EN4.

Table 9. Final rank of indicators in environmental (local) area (source: own, 2020)

\begin{tabular}{|c|c|c|c|c|c|c|}
\hline & \multicolumn{2}{|c|}{ Criterion A (weight 0.33) } & \multicolumn{2}{c|}{ Criterion B (weight 0.67) } & \multicolumn{2}{|c|}{} \\
\cline { 2 - 7 } & $\begin{array}{c}\text { Empirical } \\
\text { results }\end{array}$ & Rank & $\begin{array}{c}\text { Delphi points } \\
\text { results }\end{array}$ & Rank & $\begin{array}{c}\text { TOPSIS } \\
\text { Score }\end{array}$ & Final Rank \\
\hline EN1 & 85 & 2 & 111 & 1 & 0.889 & 2 \\
\hline EN2 & 99 & 1 & 107 & 2 & 0.959 & 1 \\
\hline EN3 & 76 & 3 & 97 & 3 & 0.762 & 3 \\
\hline EN4 & 15 & 6 & 92 & 4 & 0.389 & 4 \\
\hline
\end{tabular}


End of Table 9

\begin{tabular}{|c|c|c|c|c|c|c|}
\hline & \multicolumn{2}{|c|}{ Criterion A (weight 0.33) } & \multicolumn{2}{c|}{ Criterion B (weight 0.67) } & \multicolumn{2}{|c|}{} \\
\cline { 2 - 7 } & $\begin{array}{c}\text { Empirical } \\
\text { results }\end{array}$ & Rank & $\begin{array}{c}\text { Delphi points } \\
\text { results }\end{array}$ & Rank & $\begin{array}{c}\text { TOPSIS } \\
\text { Score }\end{array}$ & Final Rank \\
\hline EN5 & 31 & 4.5 & 81 & 5 & 0.381 & 5 \\
\hline EN6 & 6 & 8 & 75 & 6 & 0.243 & 7 \\
\hline EN7 & 31 & 4.5 & 72 & 7 & 0.314 & 6 \\
\hline EN8 & 13 & 7 & 49 & 8 & 0.059 & 8 \\
\hline
\end{tabular}

\section{Discussion}

The set of proposed indicators, that should improve reporting of social enterprises' performance, is the main output of this study.

In the social area, the first four indicators are as follows: S4, S7, S1, and S2. Indicators S1, S2, and S4 are closely related, all of them are dealing with work integration topics that naturally support the structure of social enterprises in the Czech environment. Indicators S1 and S2 are easily reachable, easy to report, and should be considered as a necessary and natural part of social enterprise reporting philosophy. Credit for these indicators is also given to numerous EU operational programs and/or national support schemes that usually ask for these indicators too. Indicators S7 and S4 have a more descriptive character, and are closely related to the essentials/principles of social entrepreneurship. Reporting all the social indicators is not difficult and could be presented in a very simple way by applying both approaches, qualitative and quantitative. Even though they cannot be collected without active cooperation from social enterprises, their reporting requires the minimum amount of effort and can be easily standardized, especially in situations when country specifics of social enterprises will be officially set.

In the economic area, the indicators are EC1, EC3, EC4, EC5. EC1 shows how successful the company is in terms of their sales, and in the Czech Republic, this indicator can be easily found in the publicly available profit and loss statements. The second indicator EC3 shows the overall ability to manage resources. As in the previous case, this indicator can be easily found at the end of the profit and loss statements (in the Czech financial statements). As for the third indicator (EC4), it could be pointed out, that this indicator is pointless when there is a legal obligation to publish the statements. However, from the verification of proposed indicators research resulted, that not all social enterprises publish them (only 168 out of 319), and thus, it was proposed rightfully. The last proposed indicator is the Mission, vision, or strategy existence (EC5). All of them (mission, vision, and strategy) have slightly different meanings, however, together they express the enterprises' ability to see itself in the present as well as in the future. The importance of their existence and the actual importance for an enterprise's success was proven many times (e. g. by Collins \& Porras, 2002 or Liker, 2004). Social enterprises publish their strategic ideas in 165 cases, which is more than half of the cases. The quality of statements differs. While some publish only their reasons for existence some publish their plans for the future (in different levels of details). To conclude, for the 
economic area, most of the proposed indicators can be easily found in the financial statements (except for EC5), which should be published obligatorily.

At the environmental/local area, the proposed indicators are EN2, EN1, EN3, EN4. All these indicators have local characteristics, some of them might be understood in an environmental way additionally. EN2, EN1, and EN3 show the level of interaction with local environment/stakeholders. This involves highlighting interaction with the community expressed in a quantitative but also a qualitative way. Further, indicator EN4 should be understood as indicator that follows previously mentioned indicators and deals with long-term impact. Evaluation of this parameter makes it difficult to identify the effect on the whole community. It should be understood as an indicator recognizing the secondary effect accompanying the work of a social enterprise. The practical application of this indicator might be seen in different ways. There are methodologies dealing with that in very sophisticated ways, however, these would not fulfill the criteria of research for this study (easy to provide, limited financial/time demands, widely applicable). Thus, another option of EN4 indicator is that it could be provided with a close relation to EN1, EN2, and EN3 by, e.g., measuring satisfaction of related stakeholders.

All proposed indicators can be easily applied in practice. With regards to the current state of using performance indicators (see section 1.1) some of these indicators correspond to Asmalovskij et al. (2019), Pelucha et al. (2017) and Vyskočil (2014), additionally to some indicators addressed to social enterprises within supporting schemes on the EU level. However, none of these approaches is so comprehensive and respecting current limitations of social enterprises (financial, time limitations etc.). Thus, proposed scheme of indicators opens the possibility for unifying and clear evaluation scheme.

\section{Conclusions}

To conclude, the proposed indicators answer a universal set of questions that can cover the standard needs of several stakeholders. As given in the theoretical background of this study, two basic approaches might be applied in social enterprise performance measurement - specific and tailored or more generalized and standardized. This study aims to confront the second one, the standardized approach, because of its possibility to be used widely, easily, to answer basic stakeholder's expectations, and without massive demands on social enterprises.

Furthermore, as mentioned in chapter 1, research in this field is processed in several ways. Research proposed in this paper confronts first and second stream and further respects 3 main perspectives that social entrepreneurship is based on (local, social and economic). With regard to these facts, proposed set of indicators respect and complete ongoing research debate. The results of the research provide a more clearly articulated path for future research. The main task for the future research is to discuss model of involvement of selected stakeholders (e.g. governmental institutions, representatives of social enterprises and other important stakeholders) in process of adopting the proposed evaluation scheme to a greater extent and to empirically confirm the possibility of applying these indicators under the circumstances as stated in the aim of this article. 
Of course, it has limitations. The first limitation was already mentioned. When a specific stakeholder expectation needs to be met or for other specific requirements, a more tailored method/indicators should be applied (see chapter 1). But, it must be noted that specific requirements ask for specific information. Thus, it has to be used when a situation asks for it, but not seen as a general effort to evaluate social enterprise performance at a glance. The second limitation dwells in data availability which is a common problem. However, the proposed set of indicators minimize such problems due to the easy accessibility of this data through publicly available sources.

Social enterprises rubric is still developing with increasing importance. It is necessary to track their development and support it by giving proper information to all subjects in their ecosystem about their usefulness. The way to do it is multifold and each approach has its pros and cons. The fact is that the rubric of performance indicators for social enterprises is dealing with the question of how to prove tangible and intangible aspects, and in the majority of situations, how to get data for such measurement. This article proposes a multidimensional system that could be elaborated upon and used for implementation. These variables could be integrated for various purposes and fields of analysis and could be used for the ex-post evaluation of the research.

\section{Author contributions}

PTP and MN conceived this study and were responsible for its conceptual design. PTP wrote the literature review. MN was responsible for research design and method. KM and VV collected the data and MN was responsible for data processing, statistical analysis and for data interpretation. PTP and MN wrote the section Conclusion.

\section{Disclosure statement}

Authors declare that they do not have any competing financial, professional, or personal interests from other parties.

\section{References}

Abu-Saifan, S. (2012). Social entrepreneurship: Definition and boundaries. Technology Innovation Management Review, 2(2), 22-27. https://doi.org/10.22215/timreview/523

Ahmad, S., \& Wong, K. Y. (2019). Development of weighted triple-bottom line sustainability indicators for the Malaysian food manufacturing industry using the Delphi method. Journal of Cleaner Production, 229, 1167-1182. https://doi.org/10.1016/j.jclepro.2019.04.399

Alarifi, G., Robson, P., \& Kromidha, E. (2019). The manifestation of entrepreneurial orientation in the social entrepreneurship context. Journal of Social Entrepreneurship, 10(3), 307-327. https://doi.org/10.1080/19420676.2018.1541015

Alegre, I., Kislenko, S., \& Berbegal-Mirabent, J. (2017). Organized chaos: mapping the definitions of social entrepreneurship. Journal of Social Entrepreneurship, 8(2), 248-264.

https://doi.org/10.1080/19420676.2017.1371631 
Arena, M., Azzone, G., \& Bengo, I. (2015). Performance measurement for social enterprises. VOLUNTAS: International Journal of Voluntary and Nonprofit Organizations, 26(2), 649-672. https://doi.org/10.1007/s11266-013-9436-8

Asmalovskij, A., Sadílek, T., Hinčica, V., \& Mizerová, M. (2019). Performance of social enterprises in the Czech Republic. Journal of Social Entrepreneurship, 10(1), 19-29. https://doi.org/10.1080/19420676.2018.1521865

Bacq, S., \& Janssen, F. (2011). The multiple faces of social entrepreneurship: A review of definitional issues based geographical and thematic criteria. Entrepreneurship \& Regional Development, 23(5-6), 373-403. https://doi.org/10.1080/08985626.2011.577242

Bagnoli, L., \& Megali, C. (2011). Measuring performance in social enterprises. Nonprofit and Voluntary Sector Quarterly, 40(1), 149-165. https://doi.org/10.1177/0899764009351111

Bednarikova, D., \& Francova, P. (2011). Studie infrastruktury sociální ekonomiky v ČR. Nová ekonomika. https://ceske-socialni-podnikani.cz/images/pdf/Studie_infrastruktury_TESSEA_plna_verze_ podzim2011.pdf

Canestrino, R., Ćwiklicki, M., Magliocca, P., \& Pawełek, B. (2020). Understanding social entrepreneurship: A cultural perspective in business research. Journal of Business Research, 110, 132-143. https://doi.org/10.1016/j.jbusres.2020.01.006

Chang, A., \& Cheng, Y. (2019). Analysis model of the sustainability development of manufacturing small and medium- sized enterprises in Taiwan. Journal of Cleaner Production, 207, 458-473. https://doi.org/10.1016/j.jclepro.2018.10.025

Chmelik, E., Musteen, M., \& Ahsan, M. (2015). Measures of performance in the context of international social ventures: An exploratory study. Journal of Social Entrepreneurship, 7(1), 74-100. https://doi.org/10.1080/19420676.2014.997781

Chráska, M. (2017). Metody pedagogického výzkumu. Grada Publishing. https://www.grada.cz/metody-pedagogickeho-vyzkumu-8365/

Collins, J., \& Porras, J. I. (2002). Built to last: Successful habits of visionary companies. HarperCollins. http://assets.globalchange.gov/j7f7/05-prof-aracely-kuphal-jr-1/rGpgorDu7-built-to-last-successful-habits-of-visionary-com.pdf

Crucke, S., \& Decramer, A. (2016). The development of a measurement instrument for the organizational performance of social enterprises. Sustainability, 8(2), 1-30. https://doi.org/10.3390/su8020161

Czech Social Entrepreneurship. (2020). Principy a definice. http://www.ceske-socialni-podnikani.cz/

Dalkey, N. C., \& Helmer, O. (1962). An experimental application of the Delphi method to the use of experts. RAND Corporation. https://www.rand.org/pubs/research_memoranda/RM727z1.html

Delbecq, A. L., Van de Ven, A. H., \& Gustafson, D. H. (1975). Group techniques for program planning. Scott Foresman Company.

Ebrahim, A., \& Rangan, V. K. (2014). What impact? A framework for measuring the scale and scope of social performance. California Management Review, 56(3), 118-141. https://doi.org/10.1525/cmr.2014.56.3.118

Egerová, D., \& Mužík, J. (2010). Aplikace metody Delphi při expertním stanovení faktorů ovlivňujících efektivnost e-learningu ve vzdělávání pracovníků v malých a středních podnicích. E+M. Ekonomie a Management, 13(2), 137-151. http://www.ekonomie-management.cz/download/1331826760_1072/13_egerova.pdf

Elkington, J. (1998). Partnerships from cannibals with forks: The triple bottom line of 21st century business. Environmental Quality Management, 8(1), 37-51. https://doi.org/10.1002/tqem.3310080106

Emerson, J. (2003). The blended value proposition: Integrating social and financial returns. California Management Review, 45(4), 35-51. https://doi.org/10.2307/41166187 
European Commission. (2020). Social enterprises and their ecosystems in Europe - Comparative synthesis report. Luxembourg Publications Office of the European Union. Luxembourg. Retrieved May 15, 2020, from https://ec.europa.eu/social/main.jsp?catId=738\&langId=en\&pubId=8274

Flostrand, A., Pitt, L., \& Bridson, S. (2020). The Delphi technique in forecasting - A 42-year bibliographic analysis (1975-2017). Technological Forecasting \& Social Change, 150, 1-12. https://doi.org/10.1016/j.techfore.2019.119773

Fraňková, E. (2019). Social enterprises and their ecosystems in Europe. Ceske socialni podnikani. Retrieved May 15, 2020, from https://ceske-socialni-podnikani.cz/images/pdf/Social_enterprises_ and_their-_ecosystems_in_Europe_Updated_country_report_Czech_Republic_final.pdf

García-Uceda, E., Murillo-Luna, J. L., \& Asín-Lafuente, J. (2017). Application of the Delphi method for the analysis of the factors determining social entrepreneurship. Journal of Business, Universidad del Pacífico, 9(1), 43-66. https://doi.org/10.21678/jb.2017.823

Gray, R. (2001). Thirty years of social accounting, reporting and auditing: What (if anything) have we learnt? Business Ethics: A European Review, 10(1), 9-15. https://doi.org/10.1111/1467-8608.00207

Gordon, T. J. (1994). The Delphi method. Futures research methodology. Retrieved May 18, 2020, from http://www.gerenciamento.ufba.br/downloads/delphi_method.pdf

Hwang, C. L., Lai, Y. J., \& Liu, T. Y. (1993). A new approach for multiple objective decision making. Computers \& Operations Research, 20(8), 889-899. https://doi.org/10.1016/0305-0548(93)90109-V

Hwang, C. L., \& Yoon, K. (1981). Methods for multiple attribute decision making. In lecture notes in economics and mathematical systems: Vol. 186. Multiple attribute decision making (pp. 58-191). Springer. https://doi.org/10.1007/978-3-642-48318-9_3

Irene, B., Marika, A., Giovanni, A., \& Mario, C. (2016). Indicators and metrics for social business: A review of current approaches. Journal of Social Entrepreneurship, 7(1), 1-24. https://doi.org/10.1080/19420676.2015.1049286

Kavoura, A., \& Andersson, T. (2016). Applying Delphi method for strategic design of social entrepreneurship. Library Review, 65(3), 185-205. https://doi.org/10.1108/LR-06-2015-0062

Kraus, S., Niemand, T., Halberstadt, J., Shaw, E., \& Syrjä, P. (2017). Social entrepreneurship orientation: Development of a measurement scale. International Journal of Entrepreneurial Behaviour and Research, 23(6), 977-997. https://doi.org/10.1108/IJEBR-07-2016-0206

Landeta, J. (2006). Current validity of the Delphi method in social sciences. Technological Forecasting and Social Change, 73(5), 467-482. https://doi.org/10.1016/j.techfore.2005.09.002

Liker, J. K. (2004). The Toyota way. McGraw-Hill Education. https://www.accessengineeringlibrary.com/ content/book/9780071392310

Linstone, H. A., \& Turoff, M. (Eds.). (1975). Introduction, In Delphi method: Techniques and applications (pp. 3-12). Addison-Wesley. https://www.worldcat.org/title/delphi-method-techniques-andapplications/oclc/1883540

Ludwig, B. (1997). Predicting the future: Have you considered using the Delphi methodology. Journal of Extension, 35(5), 1-4. http://158.132.155.107/posh97/private/research/methods-delphi/future.pdf

Maas, K., \& Liket, K. (2011). Social impact measurement: Classification of methods. In R. Burritt, S. Schaltegger, M. Bennett, T. Pohjola, \& M. Csutora (Eds.), Eco-efficiency in industry and science: Vol. 27. Environmental management accounting and supply chain management (pp. 171-202). Springer. https://doi.org/10.1007/978-94-007-1390-1_8

McLoughlin, J., Kaminski, J., Sodagar, B., Khan, S., Harris, R., Arnaudo, G., \& Mc Brearty, S. (2009). A strategic approach to social impact measurement of social enterprises: The SIMPLE methodology. Social Enterprise Journal, 5(2), 154-178. https://doi.org/10.1108/17508610910981734

Meijering, J. V., Tobi, H., \& Kern, K. (2018). Defining and measuring urban sustainability in Europe: A Delphi study on identifying its most relevant components. Ecological Indicators, 90, 38-46. https://doi.org/10.1016/j.ecolind.2018.02.055 
Musa, H. D., Yacob, M. R., Abdullah, A. M., \& Ishak, M. Y. (2015). Delphi method of developing environmental well-being indicators for the evaluation of urban sustainability in Malaysia. Procedia Environmental Sciences, 30, 244-249. https://doi.org/10.1016/j.proenv.2015.10.044

New Economics Foundation. (2007). Measuring real value: A DIY guide to social return on investment. Retrieved May 21, 2020, from http://www.neweconomics.org

OECD. (2015). Policy brief on social impact measurement for social enterprises. Policies for social entrepreneurship. Luxembourg Publications Office of the European Union. Retrieved May 26, 2020, from https://www.oecd.org/social/PB-SIM-Web_FINAL.pdf

Okoli, C., \& Pawlowski, S. D. (2004). The Delphi method as a research tool: An example, design considerations and applications. Information \& Management, 42(1), 15-29. https://doi.org/10.1016/j.im.2003.11.002

Pelucha, M., Kourilova, J., \& Kveton, V. (2017). Barriers of social entrepreneurship development - A case study of the Czech Republic. Journal of Social Entrepreneurship, 8(2), 129-148. https://doi.org/10.1080/19420676.2017.1313303

Prochazkova, P. T., \& Machova, K. (2020). Social enterprises in the Czech Republic: Selected aspects. In Proceedings of the $8^{\text {th }}$ International Conference Innovation Management, Entrepreneurship and Sustainability (pp. 622-633). Oeconomica. https://dspace5.zcu.cz/handle/11025/37046

Prochazkova, P. T., \& Noskova, M. (2020). An application of input-output analysis to social enterprises: A case of the Czech Republic. Journal of Entrepreneurship in Emerging Economies, 12(4), 495-522. https://doi.org/10.1108/JEEE-08-2019-0114

Rawhouser, H., Cummings, M., \& Newbert, S. L. (2019). Social impact measurement: Current approaches and future directions for social entrepreneurship research. Entrepreneurship Theory and Practice, 43(1), 82-115. https://doi.org/10.1177/1042258717727718

Reeder, N., \& Colantonio, A. (2013). Measuring impact and non-financial returns in impact investing: A critical overview of concepts and practice (EIBURS Working Paper 2013/01). London School of Economics and Political Science. European Investment Bank Institute. https://secities.net/wp-content/ uploads/2013/10/Measuring_Impact-full-length-Oct-2013.pdf

Saebi, T., Foss, N. J., \& Linder, S. (2019). Social entrepreneurship research: Past achievements and future promises. Journal of Management, 45(1), 70-95. https://doi.org/10.1177/0149206318793196

Somers, A. B. (2005). Shaping the balanced scorecard for use in UK social enterprises. Social Enterprise Journal, 1(1), 43-56. https://doi.org/10.1108/17508610580000706

Vyskočil, M. (2014). Podklad pro koncepci politiky vlády vi̊či NNO do roku 2020. Sociální podnikání. Retrieved May 6, 2020, from https://www.vlada.cz/assets/ppov/rnno/dokumenty/studie_vyskocil_ pro_web.pdf

Witkin, B. R., \& Altschuld, J. W. (1995). Planning and conducting needs assessment: A practical guide. Sage Publications. https://journals.sagepub.com/doi/10.1177/002087289603900316 